\title{
An analysis of male cultural hegemony in senior management in UK Academia
}

\author{
Barbara BAGILHOLE ${ }^{1}$
}

Recibido: Marzo 2014

Aceptado: Mayo 2014

\begin{abstract}
This article examines how academia in the UK is created and perpetuated by men for men. It is based on three of the author's research projects whose findings indicate patterns of discrimination in UK Higher Education (HE) institutes. The research projects collected both qualitative and quantitative data. The qualitative research involved in-depth semi-structured interviews with 80 academics, both women and men at all levels in the UK academic hierarchy. The quantitative research was undertaken via a website survey of the profiles of senior managers in UK HE institutes. The hypothesis is explored that an important mechanism for the continued narrow male-dominated senior management of $\mathrm{HE}$ is the disjuncture between formal and informal processes around university promotion. On the one hand, while transparent formal processes seek to locate promotions policies within Equal Opportunity (EO) legislation, other important informal processes are opaque, if not invisible, e.g. definitions of merit, and ways of fostering career development. Rather, these latter rely on particular forms of self-promotion, promotion by certain influential others, and subjective interpretation of policies in a way that tends to marginalise women. It is argued that male cultural hegemony, in replicating itself, perpetuates structures and practices that are insular and designed to primarily benefit a narrow group of men in senior management. These tend to be predominantly, from the disciplines in the physical sciences or engineering where men predominate. It argues that women need to challenge these structures and processes to make universities more compatible with the aspirations of women in academia and to make them more successful institutionally.
\end{abstract}

Keywords: senior management, male cultural hegemony, academia, women, UK.

\footnotetext{
${ }^{1}$ Barbara Bagilhole kindly accepted to participate in this monograph, whose publication was conceived two years ago. Unfortunately, she passed away on June 16th, 2015. This monograph is dedicated to her memory.
} 


\title{
Un análisis de la hegemonía cultural masculina en la alta dirección en la Universidad del Reino Unido
}

\begin{abstract}
RESUMEN
Este artículo examina cómo la universidad en el Reino Unido es creada y perpetuada por los hombres para los hombres. Se basa en tres de los proyectos de investigación de la autora cuyos hallazgos indican patrones de discriminación en los institutos de Educación Superior (ES) del Reino Unido. Los proyectos de investigación recogieron datos cualitativos y cuantitativos. La investigación cualitativa se basó en entrevistas semi-estructuradas en profundidad a 80 académicos, mujeres y hombres en todos los niveles de la jerarquía académica del Reino Unido. La investigación cuantitativa se llevó a cabo a través de una encuesta on-line a diferentes perfiles de alta dirección en los institutos de Educación Superior (ES). Se explora la hipótesis de que un importante mecanismo para la continuidad de una dirección de la ES, dominada por hombres, es la disyunción entre los procesos formales e informales en torno a la promoción universitaria. Por un lado, mientras que los procesos formales transparentes buscan localizar las políticas de promoción dentro de la legislación sobre Igualdad de Oportunidades (IO), otros procesos informales importantes son opacos, si no invisibles, p.e., definiciones de mérito y formas de fomentar el desarrollo profesional. Estos últimos se basan más bien en formas particulares de autopromoción, promoción por parte de otras personas influyentes, e interpretación subjetiva de las políticas de una manera que tiende a marginar a las mujeres. Se argumenta que la hegemonía cultural masculina, al replicarse, perpetúa estructuras y prácticas que son insulares y diseñadas para beneficiar principalmente a un reducido grupo de hombres en la alta dirección. Estas tendencias tienden a ser predominantes, fundamentalmente en aquellas disciplinas en las ciencias físicas o ingeniería en las que predominan los hombres. Se argumenta que las mujeres deben cuestionar estas estructuras y procesos para hacer que las universidades sean más compatibles con las aspiraciones de las mujeres en el mundo académico y para hacerlas más exitosas institucionalmente.
\end{abstract}

Palabras clave: alta dirección, hegemonía cultural masculina, universidad, mujeres, Reino Unido.

\section{INTRODUCTION}

Historically, certainly in the West, Higher Education (HE) has been seen as inappropriate, if not highly dangerous and subversive, pursuit for women and the maintenance of their femininity. Enlightenment thinkers such as Kant (1764) argued that "a woman who has a head full of Greek ... or carries on fundamental controversies about mechanics ... might as well even have a beard". Le Doeuff (2003) showed that in France even a hundred years after this rather extreme statement "nineteenth-century pedagogues such as Camille Sée, created a secondary 'education for women' in which there was little science, no Latin or Greek, and no philosophy, although there was instruction in sewing and household science" (p. xi). Jacques Derrida in his book Spurs (1978) argued that "Feminism is nothing but the operation of a woman who aspires to be like a man. And in order to resemble the masculine dogmatic philosopher this women lays claim to truth, science and objectivity in all their castrated delusions of virility. Feminism too seeks to castrate. It wants a castrated woman" (p. xi). This begs 
the question: Is he really worried about the castration of women or men? Whose virility gives him concern and is seen as threatened?

Le Doeuff (2003) coins the idea of 'ambient misogyny' to conceptualise this stream of argument in HE and the way it successfully marginalises women. This phenomenon is starkly and less 'ambiently' illustrated by an incident on December 6, 1989, when a young man gunned down 14 female engineering students in Montreal, Canada calling them feminists trying to usurp men's rightful place. She argues that "in an educational system based on carefully structured discrimination, the snail's pace of reform is obvious" (p. xi). Marge Piercy (1987) concurs in her novel 'Small Changes' about women fighting to make their way in a man's world. She had this to say about women trying to enter the academic profession: "But universities are tight and prejudiced against women. It's rotten hard for a woman to get a decent job around a university" (p.149).

This certainly seems to be the case in the UK. The history of women in UK universities is one of total exclusion until the end of the nineteenth century. For centuries women, were legally prohibited from studying in universities, obtaining a degree, and becoming an academic. Women had to fight a hard and bitter battle to enter universities. Women were not admitted to degree programmes on equal terms with men in all UK universities until $1895^{2}$. Despite women now forming the majority of students in HE, there is a continuing problem in terms of their lack of translation into academics.

The progress of women to senior positions across all industries in Britain has been tortuously slow. In 2011, at best, only $12.5 \%$ of directors of FTSE 100 Boards and $7.8 \%$ of directors of FTSE 250 Boards were women, with only $32 \%$ of FTSE100 companies disclosing the number of women directors on their Boards (Equality and Human Rights Commission, 2011). HE mirrors the general UK workforce pattern whereby women are usually well represented in universities as a whole, but there remains a serious lack of women in senior positions, particularly in academic posts. The continuing low representation of women in senior management in UK universities reflects a low recruitment pool in the professoriate. There are significant differences between the post-1992 and the 'old' (pre-1992) universities, with a few 'post 1992' universities setting good examples in terms of recruitment of women into senior management. This success is attributed to more open recruitment processes, whereas many of the older universities operate a rotating basis where an academic is elected to do 3 or 4 years in a position of management (Equality Challenge Unit, 2011).

In 2011 , across all disciplines, men comprised $55.7 \%$ of academic staff in nonmanagerial roles and $72.0 \%$ of academic staff in senior management roles. Only

\footnotetext{
${ }^{2}$ However, even after this date, women were not permitted full graduate status from Oxford and Cambridge universities. Oxford University did not admit women to full membership until 1921. At Cambridge women were not allowed to take anything but titular degrees until 1948. This was because the position of a full degree would have given them a seat on Senate and a say in university policy. Even then, both Oxford and Cambridge set quotas of $25 \%$ and $10 \%$ respectively, on the proportion of women students. Even as late as 1970, women only made up $11 \%$ of students at Cambridge.
} 
$19.1 \%$ of academic professors were women (Equality Challenge Unit, 2011). Disciplinary differences are also evident with women best represented in languagebased studies at almost every grade and worst represented in Science, Engineering and Technology (SET) (Bebbington, 2002; Blickenstaff, 2005). Data from SET departments in 2011, showed that only $15.1 \%$ of professors were female (Equality Challenge Unit, 2011). This pattern is also evident across wider subjects of Science, Technology, Engineering, Mathematics and most recently in Medicine (STEM/STEMM).

The proportion of professors is important to examine as it counts as a broad proxy for the potential recruitment pool for senior managers in Universities. From the first admittance of women to study at university to the first appointment of a woman ViceChancellor (the most senior management post in universities) in 1987 in the UK took nearly a century. In Scotland it took 108 years, with the first woman Vice-Chancellor appointment in 2003.

If we consider the management down as far as Sub-Deans in HE, as in Table 1 below, the proportion of women is $21 \%$. However, it as the top two levels that women are starkly under-represented, making up only $8 \%$ of Vice- Chancellors and $6 \%$ of Deputies.

Table 1 Senior Management by sex in UK Universities

\begin{tabular}{|l|l|l|l|l|l|l|}
\hline & \multicolumn{3}{|c|}{ Male\% } & \multicolumn{3}{c|}{ Female\% } \\
\hline & Old\% & New\% & Total & Old\% & New\% & Total \\
\hline Vice-Chancellors & 61 & 39 & 92 & 50 & 50 & 8 \\
\hline Deputy Vice-Chancellors & 57 & 43 & 94 & 33 & 66 & 6 \\
\hline Pro Vice-Chancellors & - & - & 79 & - & - & 21 \\
\hline Deans & - & - & 80 & - & - & 20 \\
\hline Sub Deans & - & - & 74 & - & - & 26 \\
\hline
\end{tabular}

Source: Bagilhole and White (2005)

The sex distribution in top level management in HE institutions is not untypical for the public sector in UK. The proportion of female Permanent Secretaries in Civil Service, and Chief Executives of local authorities is about the same as that of female heads of HE institutions. However, it is at the next level down - the equivalent of professor in HE that a real difference can be seen. In the Civil Service a quarter of the staff at a senior level are women, and in the labour market as a whole nearly a third of managers and senior officials are women. However, in HE only $13 \%$ of professors are women - just over an eighth (Warwick, 2004). Also, there is a difference in the success (no matter how small) of women attaining senior management positions in 'old' versus 'new' universities in the UK. New' universities were only awarded university status in 1992.The 'old', pre-1992 institutions are the more prestigious, research oriented and still have a higher status. However, an important caveat has to be added to the figures, 
in that we are only dealing with very small numbers. In the case of female ViceChancellors there are only eight in the whole of the UK.

It is also important to consider the discipline background of managers in HE, bearing in mind that most women professors are in the Arts and Humanities or in nursing. The following tables illustrate the lack of representation of these disciplines ${ }^{3}$.

Table 2 Senior management by sex and discipline

\begin{tabular}{|l|l|l|l|l|l|l|l|l|l|l|l|l|}
\hline & \multicolumn{2}{|l|}{$\begin{array}{l}\text { Physical } \\
\text { Science }\end{array}$} & \multicolumn{2}{l|}{ Engineering } & \multicolumn{2}{l|}{ All SET } & \multicolumn{2}{l|}{$\begin{array}{l}\text { Social } \\
\text { Sciences }\end{array}$} & \multicolumn{2}{l|}{ Humanities } & \multicolumn{2}{l|}{ Arts } \\
\hline$\%$ & $\mathrm{M}$ & $\mathrm{W}$ & $\mathrm{M}$ & $\mathrm{W}$ & $\mathrm{M}$ & $\mathrm{W}$ & $\mathrm{M}$ & $\mathrm{W}$ & $\mathrm{M}$ & $\mathrm{W}$ & $\mathrm{M}$ & $\mathrm{W}$ \\
\hline Vice- Chancellors & 4 & 0 & 5 & 0 & 9 & 0 & 9 & $8^{*}$ & 8 & $2 * *$ & 3 & 0 \\
\hline $\begin{array}{l}\text { Deputy Vice- } \\
\text { Chancellors }\end{array}$ & 8 & 0 & 8 & 5 & 6 & 25 & 26 & 25 & 4 & 50 & 4 & 0 \\
\hline $\begin{array}{l}\text { Pro Vice- } \\
\text { Chancellors }\end{array}$ & 39 & 21 & 13 & 0 & 52 & 21 & 37 & 48 & 11 & 31 & 0 & 0 \\
\hline $\begin{array}{l}\text { Deans } \\
\text { Sub Deans }\end{array}$ & 41 & $36^{*}$ & 17 & 2 & 58 & 38 & 24 & 36 & 11 & 20 & 7 & 6 \\
\hline
\end{tabular}

$* 7$ women ** 1 woman $* * *$ Over half of these are in nursing.

Source: Bagilhole and White (2005).

So, we can see that not only do men predominate in senior management in HE but also particularly men in the science, engineering and technology disciplines. It is the disciplines in the Humanities and the Arts that are particularly under-represented.

\section{WHY SO FEW WOMEN?}

This article examines how academia is created and perpetuated by men for men, and predominantly for men in the disciplines of science, engineering and technology. It explores the various dimensions of this male cultural hegemony - especially in relation to notions of merit and promotion processes - and the impact it has on institutions and staff who work in universities in the UK.

There is an enduring myth in academia that the 'best' candidates for a position or promotion are appointed. Bagilhole and Goode (2001) examined and exposed the widely held idea of an individualistic academic career that demands a certain kind of

\footnotetext{
${ }^{3}$ The UK Arts and Humanities Research Board classifies the main humanities disciplines as: archaeology, classics, history, English, history of art and architecture, linguistics, languages, library and information sciences, museum studies, musicology, philosophy, religious studies, theology, and law. Arts disciplines are; fine arts, design, visual arts and media, music, drama and dance.
} 
self-promotion, which is still perceived as an ideal model of achievement by those in senior positions. They demonstrate that there is a basic contradiction. While this idea is maintained, at the same time men gain over women through an inbuilt patriarchal support system. They do not have to make a conscious effort to be helped by it, thereby perpetuating the male cultural hegemony. Most women (and some men) are not admitted to this support system and if they are seen as needing or wanting to set up their own system in order to survive, this is viewed as a weakness. This conundrum makes HE a problematic work environment for women.

It could be argued that the introduction of equal opportunity policies in HE in the UK in the last two decades has mitigated this disadvantage for women academics. However, Bagilhole (2002a), using a theoretical lens of hegemony, develops an account of the adapting responses in the academy to the perceived demands of EO policies. She categorises these responses into four types; three different types of accommodation and one of more overt resistance. She proposes that adapting hegemony, in its different and not mutually exclusive forms, goes some way to explain the relative ineffectiveness of EO policies in an academic setting, and the maintenance of male dominance. Sinclair (1998) also warns feminists of a type of adapting masculinity in organisations that 'softens itself at the edges, which learns the language of care and consultation but uses this to strengthen the status quo' (p.74).

\section{THE DISJUNCTURE BETWEEN FORMAL AND INFORMAL PROCESSES AROUND RESEARCH AND PROMOTION}

At the heart of male cultural hegemony in HE is the notion of men as knowledge creators and women as reproducers. This is a powerful norm which means that women are expected to take greater responsibility for teaching and learning, including the pastoral care of students, rather than research (Warwick, 2004). Women academics in the UK reported higher levels of teaching and pastoral care of students than their male colleagues. Male academics discouraged students from taking up their time, and encouraged their women colleagues to take this heavier burden. This meant that men could concentrate their time and efforts on research and publishing, the activities which receive the highest rewards in terms of status, promotion and ultimately financial reward (Bagilhole, 1993a). This differentiation of roles is common across the various grades in academia (Bagilhole, 2002b). For overworked women academics research becomes a personal indulgence.

Also, in terms of management, when a woman sits on a committee it tends to be concerned with student welfare, or teaching and learning, not big expenditure, high prestige committees like planning and resources or research. Female managers are more likely to be concerned on the operational side of an institution rather than in its longer term strategy. Therefore, women do not gain experience of allocating and managing large budgets, and of being involved in making strategic decisions that would allow next step up (Warwick, 2004).

Walsh (1995) asserts that: "Acknowledging the roots of the academic and the scholarly within the psychosocial world of men has generally been resisted by male 
scholars' while men 'monopolize the construction and production of knowledge, and deploy it to their own ends' (pp. 86-7). Evans (1995) argues that 'control, rather than consumption [of the curriculum], is in the hands of men' therefore the academy's 'claims to universal and generally applicable knowledge - have to be challenged' ( $p$. 73).

\section{FORMAL PROCESSES}

EO legislation in the UK, as discussed before, provided a framework for recognising and dealing with discrimination in the workplace. However, Morley (1999) has questioned the effectiveness of public and organisational policies in bringing about change in HE. Rather, she found that for most women in academia 'equity was simply not affecting them in either material or discursive forms. It appeared that equity and feminism were operating on quite different trajectories ... Equity discourses are not theoretically framed by feminism and are not sufficiently operating as resistance to dominant epistemologies and ideologies' (p.72). Glazer-Raymo (1997) notes that 'cultural, attitudinal and structural constraints inhibit women's progress... Their cumulative impact is to call into question the liberal feminist perspective that equalizing opportunity through changes in laws and customs sufficiently motivates academic institutions to remove barriers to women's advancement' (p.198).

The ineffectiveness of organizational policies in achieving change has been demonstrated by Bagilhole and Robinson (1997) in their national study of all universities in the UK. They found that while there was a general adoption of EO policies, the problem lay with ineffective implementation and lack of action plans and resources. This demonstrated that the policies were viewed as not compulsory, and while there was a high level of lip service to these policies many were ignored or bypassed. This was also demonstrated in Bagilhole's case study (2003) of the awareness and use of liberal EO policies in a pre 1992, research oriented, UK university. She found a general lack of awareness of national EO legislation and certainly a varied level of awareness of specific EO policies within the University. The use of EO policies was extremely low, and differentiated by sex. The predicted use by respondents was similarly low and sex differentiated, with nearly two thirds of women and the vast majority of men unlikely to utilize these policies. The EO polices were perceived as differentially benefiting different groups categorised by sex and whether or not they had children. Mothers were considered to benefit most, then childless women and fathers, and finally childless men were seen to benefit least. The adoption of formal policies which stand alone is not enough, and can actually be counterproductive. A minority of respondents actually felt the policies disadvantaged different groups. Childless women were considered to be most disadvantaged, then mothers, followed by childless men and lastly fathers. In this sort of climate and environment the introduction of more radical interpretations of EO measures, although needed to allow them to be more effective, is liable to create more backlash. As Cockburn (1989) argues EO must have a 'long agenda' that includes serious measures to change the culture of the organisation and importantly the distribution of power. However, it is important to go further and acknowledge and deal with the disaffection of men 
generally, and resentment from fathers and childless women and men to these policies. Therefore, alongside training courses for all staff to address both confused and resistant attitudes, there needs to be an adequate support system and flexibility for those groups who are not traditionally considered to be the recipients of EO policies. Otherwise EO will continue to be seen as benefiting only women generally and mothers particularly, which inevitably leads to its failure.

\section{INFORMAL PROCESSES}

What are demonstrated are the structural weaknesses in formal policies and their implementation in the UK. However, it is the very complex processes of interpretation of these policies - themselves flawed - that further discriminate against women.

At the heart of this discrimination are issues around self-promotion, promotion by others, masculinist definitions of merit, and subjective interpretation of policies. Against this backdrop Bacchi (1993 talks about gender-neutrality forming "part of a broader discourse of "objectivity". It poses as "fairness" by suggesting that it is appropriate to ignore people's particular circumstances and treat them all the "same". Justice in this understanding is truly blind' (p. 38).

The subjectivity evident in informal processes is nowhere more apparent than in selection and promotion committees in academia. As Bacchi explains:

"The claim is that there is such a thing as 'ability' or 'merit' which is easily measured and indisputable [but]... 'objective criteria' only appear to be applied and in fact disguise a manipulation of details and language to achieve a desired outcome. ...And while there might be academics here who insist that our appointments committees do not fall into these sloppy habits, anyone who has served on such a committee would have reservations about the so-called merit principle (Bacchi, 1993, pp.38-9).

In Bagilhole's (2002a) study, senior academic staff were characterised by wishing to retain the power to recruit people of 'one's choice' without the intervention of bureaucratic EO procedures, which are in any case seen as ineffective since they can readily be by-passed. Senior male academics were aware of their power in terms of appointments, as the following illustrates:

"There's some satisfaction in feeling responsible for the whole thing and driving it forward as you see it ... I sat round at lunch with about twelve people and I looked round the table and I thought every one of these guys [sic] are here because of my initiatives - in terms of colleagues that I've gone out and hired, and worked hard to get, research students, PhD students and the rest of it, and that was a good feeling ... a lot of effort to get who was right for that position to carry it forward with whatever vision you've got. I think one of the big problems is the sense of 'we're looking for the best person, we don't want to tie ourselves down beforehand in case the best person comes through the door, and we've ruled them out by being too prescriptive". 
This quote suggests the notion of social cloning that occurs in promotion to senior positions in HE, which counters the possibility of cross-gender and cross-disciplinary fertilisation. As Bagilhole (1993a) argued this often ensures that the 'best man for the job is appointed'. The empowerment highlighted here suggests that informal processes are at work. As Lorber (1994) explains: 'Parallel to the formal organisation of a large, modern workplace ... is the informal organisation, which is based on trust, loyalty and reciprocal favours. ... Trust and loyalty are built through homosociality'. She argues further that for the most part, as colleagues, friends, and wives, women are relegated to acting as audience or sex objects for men' (p.233).

\section{PERPETUATING MALE CULTURAL HEGEMONY}

Male hegemony in universities is self-perpetuating. The next generation of leaders is created in the image of those who have gone before them. While the literature suggests that leadership in most organisations tends to replicate itself, the insidious nature of the replication in universities is that it operates from such a narrow base. It is time that male cultural hegemony in universities was subjected to close scrutiny. What is it about? How is it perpetuated? Who benefits from it?

Bagilhole (2002a) argues that what can be found in universities (drawing from Connell 1987 and Gramsci, 1988) - is 'accommodating' and adapting masculine hegemony. In addition, the issue of where power is located in the organization is important. Senior academic staff (predominantly male scientists and engineers) in UK universities remain essentially autonomous and therefore difficult to manage.

Lorber (1994) argued that those in power in HE organized colleagues, informally into three concentric circles - inner circles, friendly colleagues, and isolated loners. Power was concentrated and policy was made in the inner circles. Not all men reached this inner circle and although women were not totally excluded from the informal colleague network, they were rarely groomed to be part of the inner circle.

Different treatment for male and female academics is often experienced from the outset of their careers. Younger male academics feel able to ask for help from powerful superiors 'within the male community of work, younger men appear to assume that older men should help them because they need help whereas women do not appear to expect assistance from superiors based on their needs' (Martin, 1996, p.203). In fact, far from expecting assistance, woman academics feared possible prejudice against their career (Bagilhole 2002a). As Lorber (1994) argued the reality for women in a predominantly man's occupation is that at some time or another, often a crucial time, she will realise that her male colleagues never really considered her 'one of them'. It could therefore be argued that early in academic careers there are different patterns of mentoring for men and women.

If this system of leadership in universities contributed to the 'greater good' whatever that means, it might have some legitimacy. However, it does not necessarily produce good scholarship, good research or socially useful outcomes. Unfortunately, the Government White Paper on Higher Education in the UK (2003) with its proposed 
concentration of research money in only a few élite universities, openly encouraged competition between academics to become the one who receives the 'pot of gold', thereby depriving many good researchers elsewhere whose universities are not one of the chosen few. This disproportionately impacts on women academics who are more likely to be found in the new post-1992 universities, which are less likely to receive this research money.

This male emphasis on winning means that male leadership focuses on backing and picking winners. The 'betting ring' in HE is the promotion committee. Here, the male cultural hegemony faces the challenge of subverting the formal processes of promotion to select their own candidates, as discussed before. Bagilhole and Goode (2001) note that the male system is about 'cultivating a system of active promotion by others'. This is subjective and may compromise the promotions process.

"Moreover, the system of academic referees being required to support promotion applications can be problematic for women, in a pervasive culture where their achievements may be valued and evaluated differently from those of male peers especially with the emphasis on and rewarding of research oriented activities" (Goode and Bagilhole, 2001).

There has been a great deal written about the under-representation of women in senior academia in the UK. Much of the focus was on the 'deficit' model that explains why women have not achieved representation in senior academic positions in proportion to their numbers by locating the problem in women themselves. However, the real emphasis in this debate needs to be on the narrow group of men who exert power in universities. As Le Doeuff (2003) argues 'the blatant ways in which intellectual institutions attempt to perpetuate as much masculine domination as possible' (p. x). As Glazer-Raymo (1999, p.205) argues 'it would be more appropriate to determine what makes institutional structures more compatible with men's lives'.

A narrow executive profile exists in HE in the UK. Male managers tend to promote those with a similar profile. Thornton (2000) explains that 'within the university, the key decision makers, or gatekeepers... are invariably men - white Anglo-Celtic, heterosexual, able-bodied, middle-class men. [They] tend to favour those who most look like themselves' including one could add those from a similar disciplinary background. Women are excluded from this 'boys' club', often in subtle ways. The formal and informal networks that operate within senior management are at the core of this male hegemony (Moore, 1999). The exclusion is clearest in promotion policies and processes in HE which act as a 'gateway' against women by being interpreted subjectively (Wyn, 1997). Also, peer review generally and specifically for research grant applications to national Research Councils stand accused of the potential for a certain amount of nepotism and 'turn-taking' with male academics awarding grants to other male academics who subsequently take their turn on the awarding body and 'pay their dues' (Goode and Bagilhole, 2001).

Given this narrow executive profile, it might be argued that no women would be promoted to senior management. Clearly, some women do get promoted but often pay a price. Many women must first pay homage to what Thornton (2000) calls 'The 
Benchmark Men' in universities if they wish to be promoted to leadership roles. Ironically, many women who achieve leadership roles in universities merely replicate the behaviour of this narrow management profile. The reason is that senior managers tend to promote token women. Once token women are promoted into top academic positions they are made ineffectual:

'Even if a 'token' woman is allowed to enter the pipelines of power, they are actively discouraged in recruiting more 'like them' or from competing with men for the very top positions. In this way, men maintain their values and ideas as the dominant ones and ensure the continued success of people as similar as possible to themselves" (Bagilhole, 2002a, p. 9).

This adds up to the conditional inclusion of a small number of women, which Le Doeuff (2003) calls the conditions for 'secondary entry'. Thus the presence of token women in leadership roles in HE does nothing to further the position of the majority of women. Although it could be argued that token women have symbolic importance by demonstrating that some women can reach senior positions, elite women in universities can also use hierarchies to promote their own careers and exploit and marginalise subordinates.

The exclusion of women in the workplace is recognised as a symptom of deeper problems requiring solutions focusing on the existing culture. This is extremely important as research in the UK (Bagilhole, 1993b) has shown that women students gravitate towards modules taught by women lecturers and that women academics are aware of their tendency to support and help women students. The need for senior women academics as role models for postgraduate research students has also been identified.

\section{CHALLENGING THE STRUCTURES AND PROCESSES IN HE}

This paper has argued that women academics need to challenge these structures and processes to make universities meritocratic and more compatible with the talents and aspirations of women in academia, if they are to experience rewarding careers. Too often, as Lorber (1994) observes'as a result of accumulation of disadvantages, women often have stop and go careers that may start out well, but then flounder' (p.238).

Bacchi (1993) favoured a reversal of the strategy of trying to win concessions for women to increase their representation in senior positions, to the demand for more female senior academics:

"Let us interrogate appointments procedures, instead of accepting the current designation of merit. It is time to direct attention to the standards by which men have been assessed, rather than continuing to try to win some 'concession' for women. Instead of women explaining what attributes they can be expected to bring to the job, let us ask male academics to demonstrate their 'merit', to justify their over-representation" (p.39).

The more usual line of argument for diversifying senior positions in HE and including more women is that they can bring extra and different dimensions, skills and approaches to the present pre-dominantly male body, and importantly this will benefit 
HE. Typical of this approach is Warwick's (2004) argument.

"There is a need to introduce an extended range of management styles and skills. Certainly to extend them beyond the prevailing masculine models of behaviour, which were developed to serve an overwhelmingly male profession. ... There are sound business reasons for adapting and challenging existing structures. Not least of these are those that relate to recruitment, retention and satisfaction of staff working in the sector" (p.5).

The logic behind this is that academics in the UK are an ageing profession and universities will need to look to women to replace retiring staff.

However, importantly this places women's equality as a 'means' to 'business ends'. Characteristically, Le Doeuff (2003) asks us to look beyond and above this classic, relatively safe and acceptable political argument for rectifying the underrepresentation of women in many institutions within society. She argues for the position where women's equality is an end in itself, not the means to other ends.

"Currently, campaigns for women's entry into the sciences ... or for more equity ... are based on the claim that the sciences would benefit and that new fields of study or new methods would appear. ... there is still a problem: women are looked upon as means, in this instance as the means to a scientific renewal - means, as usual, for achieving a good that would not initially be theirs. So to the extent that we must endorse the general idea that more justice for women will produce positive effects for everyone, we must also and first of all take women themselves as ends rather than means. People too often miss the point: even when justice for women would imply no particular benefit of anyone but them or for institutions, it would still be intrinsically valuable. It thus becomes a matter of simple justice to make the scientific world more equitably mixed" (pp.162-3).

\section{CONCLUSION}

This article set out to examine how academia is created and perpetuated by men for men. It has explored the hypothesis that an important mechanism for the continued narrow male-dominated senior management of $\mathrm{HE}$ in the $\mathrm{UK}$ is the disjuncture between formal and informal processes around university appointments and promotions. It then examined the further hypothesis that male cultural hegemony, in replicating itself, perpetuates structures and practices that are insular and designed to benefit only a narrow group of men in senior management.

The article argued that women need to challenge these structures and processes to make universities more compatible with their aspirations. In particular it is important to put the mechanisms and processes within HE that perpetuate the under-representation of women under the microscope. As is being gradually recognised and acknowledged, rather than try to win piecemeal concessions for women, it is time for a root and branch review as a basis for determining the skills which are needed for future academic managers and leaders in UK HE. 


\section{REFERENCES}

BACCHI, CAROL (1993): The Brick Wall: Why so few women become senior academics, The Australian Universities Review, 36(1), 36-41.

BAGILHOLE, BARBARA (2004): Website Survey of Senior Management in UK Universities. UK: Loughborough University.

BAGILHOLE, BARABARA (2003): One step forward and two steps back? A case study of a strategy to promote gender equality in a UK university and the resistance it encountered, in Valeria Maione (ed) Gender Equality in Higher Education. Miscellanea Third European Conference, University of Genova, Italy (pp.31-52).

BAGILHOLE, BARBARA (2002a): Challenging Equal Opportunities: Changing and adapting male hegemony in academia, British Journal of Sociology of Education, 23(1), 19-33.

BAGILHOLE, BARBARA (2002b): Women in non-traditional occupations: Challenging Men. London: Palgrave Macmillan.

BAGILHOLE, BARBARA (1993a): How to keep a good woman down: An investigation of the role of institutional factors in the process of discrimination against women academics, British Journal of Sociology of Education, 14(3), 26174.

BAGILHOLE, BARBARA (1993b): Survivors in a Male Preserve: A Study of British women academics experiences and perceptions of discrimination in a UK University, Higher Education, 26, 431-47.

BAGILHOLE, BARBARA and GOODE, JACKIE (2001): The Contradiction of the Myth of Individual Merit, and the Reality of a Patriarchal Support System in Academic Careers: A Feminist Investigation, European Journal of Women's Studies, 8(2), 161-80.

BAGILHOLE, BARBARA and ROBINSON, ELAINE (1997): A Report on Policies and Practices on Equal Opportunities in Employment in Universities and Colleges of Higher Education, Commission on University Career Opportunity, Committee of Vice-Chancellors and Principals of the Universities of the United Kingdom (CVCP), London.

BAGILHOLE, BARBARA and WHITE, KATE (2005): Benign burden: Gender and senior management in the UK and Australia. Paper presented at the 4th European Conference on Gender Equality in Higher Education, Oxford. 
BEBBINGTON, DIANE (2002): Women in Science, Engineering and Technology: A Review of the Issues, Higher Education Quarterly, 56, 360-375.

BLICKENSTAFF, JACOB C. (2005): Women and science careers: leaky pipeline or gender filter? Gender and Education, 17, 369-386.

CONNELL, RAEWYN W. (1987): Gender and Power: Society, the Person and Sexual Politics. Cambridge: Polity Press.

Equality Challenge Unit (2011): Equality in higher education: statistical report 2011. Part 1: staff. http://goo.gl/KRryWp

Equality and Human Rights Commission (2011): Sex and Power. London: Equality and Human Rights Commission.

EVANS, MARY (1995): Ivory Towers: Life in the Mind, in Louise Morley and Val Walsh, (Eds) Feminist Academics: Creative Agents for Change. London: Taylor and Francis.

GLAZER-RAYMO, JUDITH (1999): Shattering the Myths: Women in Academe. Baltimore: The Johns Hopkins University Press.

GRAMSCI, ANTONIO (1988): Some theoretical and Practical aspects of 'Economism', in David Forgacs and Eric J. Hobsbawm (Eds), The Antonio Gramsci Reader. Selected Writings 1916-1935, London: Lawrence and Wishart.

KANT, IMMANUEL (2007): Observations on the Feeling of the Beautiful and Sublime. Edited by Günter Zöller and Robert B. Louden. Cambridge: Cambridge University Press.

LE DOEUFF, MICHÈLE (2003): The Sex of Knowing. London: Routledge.

LORBER, JUDITH (1994): Paradoxes of Gender. New Haven: Yale University Press.

MARTIN, PATRICIA Y. (1996): Gendering and Evaluating Dynamics: Men, Masculinities, and Managements, in David L. Collinson and Jeff Hearn (Eds) Men as Managers, Managers as Men. London: Sage.

MORLEY, LOUISE (1999): Organising Feminisms: The micropolitics of the academy. New York: St Martin's Press.

PIERCY, MARGE (1987): Small Changes. London: Penguin.

THORNTON, MARGARET (2000): Dissonance and Distrust: Women in the Legal Profession. Melbourne: Oxford University Press. 
WALSH, VAL (1995): Transgression and the Academy: Feminists and Institutionalization, in Louise Morley and Val Walsh, (Eds) Feminist Academics: Creative Agents for Change. London: Taylor and Francis.

WARWICK, DIANA (2004): Women and Leadership: A Higher Education Perspective, The Barbara Diamond Memorial Lecture, University of Westminster. Universities UK Chief Executive. 